Centre for Research on

Drugs and Health Behaviour, Charing Cross and Westminster Medical School, London SW6 1RQ Paul J Turnbull, BA, research worker

Gerry V Stimson, MRCPSYCH, professor

Kate A Dolan, BSC, research fellow

Correspondence to: Mr Turnbull.

BMf 1992;304:90-1 medical advice for them. Men as well as women often experience these symptoms, and consultation behaviour is likely to explain previous assertions that irritable bowel syndrome is experienced predominantly by women. The patients with the syndrome reported here also had rectal bleeding much more commonly than subjects without the syndrome, but consultation rates for rectal bleeding are also low.

We still have a poor understanding of the triggers to consultation among these patients. Studies from North America have reported that psychopathology is more frequent in consulting than non-consulting patients with irritable bowel syndrome but is not a feature of the syndrome itself. ${ }^{1725}$ More research is required to clarify patients' reasons for seeking medical advice and their expectations of their medical attendants so that the clinical care of patients with these common symptoms can be improved.

We thank all the participating general practitioners and their patients for their cooperation, the Scientific Foundation Board of the Royal College of General Practitioners and Duphar Laboratories Ltd for their support, and Professor Michael Farthing for helpful suggestions.

1 Mitchell CM, Drossman DA. Survey of the AGA membership relating to patients with functional gastrointestinal disorders. Gastroenterology 1987;92: patients

2 Ingham JG, Miller PM. Symptom prevalence and severity in a general practice population. 7 Epidemiol Commun Health 1979;33:191-8.

population. $\mathrm{F}$ Epidemiol Commun Health 1979;33:191-8.
Drossman DA, Sandler RS, McKee DC, Lovitz AJ. Bowel patterns among subjects not seeking health care. Gastroenterology 1982;83:529-34.

4 Thomson WG, Heaton KW. Functional bowel disorders in apparently healthly people. Gastroenterology 1980;79:283-8.

5 Jones RH, Lydeard SE. Prevalence of symptoms of dyspepsia in the community. BM 1989;298:30-2.

6 Lydeard SE, Jones RH. Factors affecting the decision to consult with dyspepsia: comparison of consulters and non consulters. $\mathcal{F} R$ Coll Gen Pract 1989;39:495-8.

\section{Prevalence of HIV infection among ex-prisoners in England}

\section{Paul J Turnbull, Gerry V Stimson, Kate A Dolan}

7 Manning AP, Thompson WG, Heaton KW, Morris AF. Towards positive diagnosis of the irritable bowel. BMF 1978; ii: $653-4$.

8 Thompson WG. Gastrointestinal symptoms in the irritable bowel compared with peptic ulcer and inflammatory bowel disease. Gut 1984;25:1089-92.

9 Talley NJ, Phillips SF, Melton LJ, Mulvihill C, Wiltgen C, Zinsmeister AR. Diagnostic value of the Manning criteria in irritable bowel syndrome. Gut 1990;31:77-81.

10 Smith RC, Greenbaum DS, Vancouver JB, Henry RC, Reinhart MA, Greenbaum RB, et al. Gender differences in Manning criteria in irritable bowel syndrome Gastroenterology 1991;100:591-5.

11 Whorwell PJ, Lupton EW, Erduran D, Wilson K. Bladder smooth muscle abnormalities in patients with irritable bowel syndrome. Gut 1986;27: 1014-7.

12 Sandler RS, Drossman DA, Nathan H. Symptom complaints and health care seeking behaviour in subjects with bowel dysfunction. Gastroenterology $1984 ; 87: 314-8$.

13 Whorwell PJ, McCallum M, Creed FH, Roberts TC. Non-colonic features of irritable bowel syndrome. Gut 1986;27:37-40.

14 White AM, Stevens WH, Upton AR, O'Byrne PM, Collins SM. Airway responsiveness to inhaled methacholine in patients with irritable bowel syndrome. Gastroenterology 1991;100:68-74.

15 Isgar B, Harman M, Kaye MD, Whorwell PJ. Symptoms of irritable bowel syndrome in ulcerative colitis in remission. Gut 1983;24:190-1.

16 Heaton KW, Ghosh S, Braddon FEM. How bad are the symptoms and bowel dysfunction of patients with irritable bowel syndrome? Gut 1991;32:73-9.

7 Smith RC, Greenbaum DS, Vancouver JB, Henry RC, Reinhart MA,

Greenbaum RB, et al. Psychological factors are associated with health care Greenbaum RB, et al. Psychological factors are associated with health care seeking rather than

18 Talley NJ, Phillips SF, Bruce B, Twomey CK, Zinsmeister AR, Melton LJ. Relation among personality and symptoms in non-ulcer dyspepsia and the Relation among personality and symptoms in non-ulcer dy
irritable bowel syndrome. Gastroenterology 1990;99:327-33.

19 Bordie AK. Functional disorders of the colon. F Indian Med Assoc 1972;58: $451-5$.

20 Mendis BLJ, Wijesiriwardena BC, Sheriff MHR, Dharmadason K. Irritable bowel syndrome. Ceylon Med $\mathcal{F}$ 1983;27:171-81.

21 Goudy WJ. Interim response to a mail questionnaire: impacts on variable relationships. Iowa State University, 1976. (Iowa Agriculture and Home Economics Experiment State journal paper No 3.)

22 Thompson WG. Gut reactions: understanding symptoms of the digestive tract. London: Plenum, 1989.

23 Dent OF, Goulston KJ, Zobrzyck J, Chapuis PH. Bowel symptoms in an apparently well population. Dis Colon Rectum 1986;29:243-7.

24 MacDonald L, Freeling P. Bowels: beliefs and behaviour. Family Practice 1986;3:80-4

25 Drossman DA, McKee DC, Sandler RS, Mitchell CM, Cramer EM, Lowman $\mathrm{BC}$, et al. Psychosocial factors in the irritable bowel syndrome: a multivariate study of patients and non-patients with irritable bowel syndrome. Gastroenterology 1988;95:701-8.

(Accepted 1 October 1991)

( $55 \%$ had served over 12 months). Risk behaviour data are reported elsewhere. ${ }^{3}$

Saliva samples were collected from 402 subjects. Positive results for HIV antibodies were obtained in 19 and negative results in 366 (17 samples were too small to test). The largest proportion of people who were HIV positive was found in the injecting group at $10 \cdot 1 \%$ (table I); the rate for women who injected $(15.5 \%)$ was twice that for men. Rates of HIV infection were relatively low in other groups, but HIV infection was found among non-injecting heterosexual men and noninjecting women. HIV infection in these samples may indicate possible heterosexual transmission or transmission via blood products, but earlier unsafe injection or homosexual behaviour cannot be excluded as a risk factor.

Ex-prisoners in England: results of testing saliva samples for HIV antibodies

\begin{tabular}{|c|c|c|c|}
\hline \multirow[b]{2}{*}{ Group } & \multirow[b]{2}{*}{ No tested } & \multicolumn{2}{|c|}{ HIV antibody positive } \\
\hline & & No (\%) & $\begin{array}{l}95 \% \text { Confidence } \\
\text { interval }(\%)\end{array}$ \\
\hline Injectors: & 148 & $15(10 \cdot 1)$ & $5 \cdot 3$ to 14.8 \\
\hline Men & 103 & $8(7 \cdot 7)$ & 2.6 to 12.8 \\
\hline Women & 45 & $7(15 \cdot 5)$ & $5 \cdot 0$ to $26 \cdot 0$ \\
\hline $\begin{array}{l}\text { Non-injecting } \\
\text { women }\end{array}$ & 29 & $1(3 \cdot 4)$ & -3.1 to 9.9 \\
\hline $\begin{array}{l}\text { Homosexual/bisexual } \\
\text { men }\end{array}$ & 20 & $\begin{array}{l}0 \\
3(1 \cdot 6)\end{array}$ & \\
\hline Others & 188 & & $-0 \cdot 1$ to $3 \cdot 3$ \\
\hline
\end{tabular}
hundred and seventy one were men, and ages ranged from 14 to 62 with a mean of 27 years. The sample was not randomly selected, but was similar to the prison population in the proportion on remand $(20 \%)$ and the type of sentences. Between them the respondents had been in at least $63 \%$ of prisons and young offenders' institutions in England and Wales. Our sample underrepresented people who had served short sentences

\section{Comment}

Our group of subjects was similar to the general prison population in several characteristics and allows some provisional estimate of the prevalence of HIV in prison. Extrapolation from the data of Maden et al 
indicates that about 2540 men in the sentenced prison population injected drugs in the six months before arrest. ${ }^{45}$ If we assume from our data that $8 \%$ of them were HIV positive that gives an estimated total of 203 HIV positive male drug injectors in the sentenced population. The corresponding figures for women (about 168 recent injectors, and 15\% HIV positive) suggest a total of $25 \mathrm{HIV}$ positive women in prison. At any time, therefore, the total number of HIV positive prisoners may be about 228 in a sentenced population of about 36000 .

If drug injecting is found as commonly among remand prisoners as amongst those sentenced the total number of HIV positive drug injectors in the prison system (both sentenced and on remand) is probably about 285 out of a prison population of about 45000 , or 1 in 158. It is more difficult to estimate the prevalence of HIV infection among non-injecting prisoners. We found that $1 \cdot 7 \%$ of the non-injecting subjects were HIV positive but it is difficult to make a projection when prevalence is low.

On the basis of the evidence for drug injectors, we conclude that the prevalence of HIV infection in the prison population is not less than about 1 in 158 $(0.6 \%)$. This estimate must be compared with the prison department's figure of roughly 50 prisoners known to be positive for HIV antibody per year.

1 Farrell M, Strang J. Drugs, HIV, and prisons. BMF 1991;302:1477-8.

2 Johnson AM, Parry JV, Best SJ, Smith AM, DeSilva M, Mortimer P. HIV surveillance by testing saliva. AIDS 1988;2:369-71.

Turnbull PJ, Dolan KA, Stimson GV. Prisons, HIV and AIDS: risks and experiences in custodial care. Horsham: AVERT, 1991.

4 Maden A, Swinton M, Gunn J. Drug dependence in prisoners. BM $\mathcal{J}$ 1991;302:880.

5 Maden A, Swinton M, Gunn J. Women in prison and use of illicit drugs before arrest. BMF 1991;301:1133.

(Accepted 25 September 1991)

\title{
A clinical trial of minocycline in lepromatous leprosy
}

\author{
Robert H Gelber, Keiji Fukuda, Sally Byrd, \\ L P Murray, P Siu, M Tsang, Thomas H Rea
}

\section{Hansen's Disease Research Program, San Francisco, California 94115-1896, USA Robert H Gelber, MD, medical director \\ Keiji Fukuda, MD, clinical associate \\ Sally Byrd, MD, clinical associate \\ L P Murray, senior research assistant \\ P Siu, BS, senior research assistant \\ M Tsang, BS, senior research assistant \\ Division of Dermatology, University of Southern California School of Medicine, Los Angeles, California 90033, USA \\ Thomas H Rea, MD, chairman}

Correspondence to: Dr Gelber.

$B M \mathcal{F} 1992 ; 304: 91-2$
Not since 1970, when Rees showed that rifampicin was effective against Mycobacterium leprae in infected mice and rapidly bactericidal in patients with lepromatous leprosy, ${ }^{1}$ has a new chemotherapeutic agent been introduced to treat leprosy. Drugs for treating leprosy worldwide are limited to dapsone, clofazimine, and rifampicin; this small number is of special concern because of the emergence of drug resistant disease, the general recommendation of multiple drug treatment, and significant side effects and toxicities of each of these drugs, which at times preclude their use. We showed that minocycline at concentrations achievable in humans was active against $M$ leprae in mice and consistently bactericidal. ${ }^{23}$ We therefore initiated a clinical trial of minocycline in patients with lepromatous leprosy.

\section{Patients, methods, and results}

Eight consenting adults (seven men and one woman) with lepromatous leprosy (five patients) or borderline lepromatous leprosy (three) who had been previously untreated (six) or whose leprosy had relapsed (two) were treated with $100 \mathrm{mg}$ minocycline alone once daily for three months.

After one week's treatment we observed improvement in either skin erythema or induration in six patients and improvement in both manifestations in two. After three months' treatment skin lesions had noticeably improved in all patients, six patients having complete resolution of all erythema and induration. One patient had mild transient vertigo, which resolved spontaneously without discontinuing treatment. No other adverse reaction was noted. Unexpectedly, none of the patients developed a lepra reaction.

Before treatment and at one week and one, two, and three months after starting treatment skin biopsies were performed, from which $5 \times 10^{3} \mathrm{M}$ leprae were inoculated into the hind feet of $\mathrm{BALB} / \mathrm{c}$ mice. If more than $10^{5}$ acid fast bacilli per foot pad were found in pooled foot pads (four) harvested eight and 12 months subsequently or in one foot pad or more of those (generally 10 ) counted individually 12 months after infection, viable bacilli were considered to have been present in the inoculum.
All of the pretreatment skin biopsy specimens consistently resulted in growth of the bacilli in mice when evaluated by both methods. According to the findings of pooled harvests of foot pads no patient harboured any viable $M$ leprae at either two or three months after starting treatment (table). Harvests of individual foot pads were more sensitive in detecting any viable $M$ leprae; in six instances these results were positive and those of pooled harvests were negative, and in none was the opposite true (table). Viable bacilli were consistently absent from the skin in only one patient at one week after treatment. At one and two months respectively three and six of the patients had lost detectable viable leprosy bacilli, and by three months none of the eight patients harboured any viable bacilli.

Serum minocycline concentrations determined by an agar disc diffusion method ${ }^{2}$ were at the peak (two hours after treatment) $1.84($ SD 0.48$) \mathrm{mg} / \mathrm{l}$ (range 1.07 $2.66 \mathrm{mg} / \mathrm{l})$ and at the trough (24 hours after treatment) $0.43(0.11) \mathrm{mg} / \mathrm{l}$ (range $0.33-0.58 \mathrm{mg} / \mathrm{l})$, well above that $(\leqslant 0.17 \mathrm{mg} / \mathrm{l})$ previously found to inhibit consistently growth of $M$ leprae in mice. ${ }^{23}$

Viability of $M$ leprae in skin biopsy specimens from patients with lepromatous or borderline lepromatous leprosy treated with minocycline

\begin{tabular}{|c|c|c|c|c|c|}
\hline \multirow{2}{*}{$\begin{array}{l}\text { Patient } \\
\text { No }\end{array}$} & \multirow{2}{*}{$\begin{array}{c}\text { Pooled harvests }{ }^{\star} \text { or } \\
\text { individual harvest } \\
\text { mouse foot pads }\end{array}$} & \multicolumn{4}{|c|}{ Time after starting treatment } \\
\hline & & 1 Week & 1 Month & 2 Months & 3 Months \\
\hline 1 & $\begin{array}{l}\text { Pooled }(n=4) \\
\text { Individual }(n=10)\end{array}$ & $\begin{array}{c}+1+ \\
5\end{array}$ & $\begin{array}{c}-1+ \\
6\end{array}$ & $\begin{array}{c}-1- \\
1\end{array}$ & $\begin{array}{c}-1- \\
0\end{array}$ \\
\hline 2 & $\begin{array}{l}\text { Pooled }(n=4) \\
\text { Individual }(n=10)\end{array}$ & $\begin{array}{c}+/+ \\
3\end{array}$ & $\begin{array}{c}-1- \\
4\end{array}$ & $\begin{array}{c}-1- \\
0\end{array}$ & $\begin{array}{c}-1- \\
0\end{array}$ \\
\hline 3 & $\begin{array}{l}\text { Pooled }(n=4) \\
\text { Individual }(n=10)\end{array}$ & $-1-$ & $+1-$ & $\begin{array}{c}-1- \\
0\end{array}$ & $\begin{array}{c}-1- \\
0\end{array}$ \\
\hline 4 & $\begin{array}{l}\text { Pooled }(n=4) \\
\text { Individual }(n=10)\end{array}$ & $-1-$ & $\begin{array}{c}-1- \\
0\end{array}$ & $\begin{array}{c}-1- \\
0\end{array}$ & $\begin{array}{c}-1- \\
0\end{array}$ \\
\hline 5 & $\begin{array}{l}\text { Pooled }(n=4) \\
\text { Individual }(n=10)\end{array}$ & $\begin{array}{c}-1- \\
0\end{array}$ & $\begin{array}{c}-1- \\
0\end{array}$ & $\begin{array}{c}-1- \\
0\end{array}$ & $\begin{array}{c}-1- \\
0\end{array}$ \\
\hline 6 & $\begin{array}{l}\text { Pooled }(n=4) \\
\text { Individual }(n=10)\end{array}$ & $-1+$ & $\begin{array}{c}-1- \\
0+\end{array}$ & $\begin{array}{c}-1- \\
0\end{array}$ & $\begin{array}{c}-1- \\
0\end{array}$ \\
\hline 7 & $\begin{array}{l}\text { Pooled }(n=4) \\
\text { Individual }(n=10)\end{array}$ & $\begin{array}{c}-1- \\
1\end{array}$ & $\begin{array}{c}+/+ \\
5\end{array}$ & $-1-$ & $-1-$ \\
\hline 8 & $\begin{array}{l}\text { Pooled }(n=4) \\
\text { Individual }(n=10)\end{array}$ & $+1-$ & $\begin{array}{c}-1+ \\
5\end{array}$ & $-1-$ & $\begin{array}{c}-1- \\
0\end{array}$ \\
\hline
\end{tabular}

$\star$ Eight month harvest/12 month harvest.

$+n=8$.

+ - - Presence/absence of viable $M$ leprae.

\section{Comment}

The consistent rapidity of the patients' clinical response to minocycline is unique in our experience. The clearance of viable $M$ leprae from the skin by minocycline was faster than that reported for dapsone or clofazimine, ${ }^{4}$ slower than that for rifampicin,,$^{14}$ and similar to that for pefloxacin and ofloxacin." 